\title{
Hydrology of a tropical rain forest in Suriname
}

\author{
R. L. H. POELS \\ Department of Soil Science and Geology, Agricultural University, P.O. Box 37, NL 6700 \\ AA, Wageningen, Netherlands
}

Received 9 June 1989; accepted 21 August 1989

\begin{abstract}
Rainfall and discharge were measured for almost 5 years in a 300 ha forested watershed in Suriname. Groundwater levels were measured for 2 years. The hydrological data were used in a simulation model for plant growth. Estimates were made on effective rooting depth, transpiration reduction in the dry season, and the contribution of interception to total water use. Possible relations between hydrological characteristics of the forest and nutrient cycling are given.
\end{abstract}

Keywords: hydrology, rain forest, Suriname, catchment, rooting depth, interception, simulation model

\section{Introduction}

Research was carried out in Suriname to define optimal land use systems for tropical rain forest areas (Boxman et al., 1985). Both forestry and agricultural (annual crops) land uses were studied. Agricultural land uses were seriously constrained by low fertility and low nutrient holding capacity of the soil. Silviculture in natural forests showed better results than silviculture in plantations (de Graaf, 1986), because of weed problems in the latter but probably also because of a more closed nutrient cycling in the natural forest.

Hydrology was expected to be the clue to understanding of the nutrient cycling, because nutrient transport is largely caused by water movements. The hydrology of the tropical rain forest was studied as part of a comprehensive research program on the ecological sustainability of a silvicultural system for natural regeneration (de Graaf, 1986).

\section{The study area}

The area is slightly undulating, with an average slope of about $4 \%$. Geologically, it consists of a residual gravelly clay substratum of Precambrian age covered with Pliocene sediments of the Zanderij Formation. These sediments have an average thickness of about $3 \mathrm{~m}$, a sandy loam to sandy clay texture, a mineralogy of quartz 
and kaolinitic clay and have been deposited as coalescing alluvial fans. The main soil developed in these sediments is a well-drained loamy Ultic Haplorthox, that covers most of the plateaus and upper slopes, while sandy hydromorphic soils occur on lower slopes and in valley bottoms. The area is drained by small creeks with a nearly year-round flow, discharging mainly groundwater. Infiltration capacity is high and overland flow is rare even during heavy rain storms.

\section{Measurement of hydrological data}

A catchment area of 295 ha, covered with mesophytic tropical rain forest was used in the study. In half of the catchment the forest was left undisturbed, in the other half it received a silvicultural treatment that, however, had no noticeable effect on the hydrology. At the lower end of the catchment area, a dam with a sharp crested triangular weir was built in the creek bed to measure the outflow of water. Discharge was calculated from water levels in front of the weir recorded every 15 minutes. Rainfall was recorded with two rain gauges: an automatic rainfall recorder for 30 minute periods and a hand-operated rain gauge for daily totals. Evaporation was measured with a Class A evaporation pan. Measurements were continued for 4 years and 9 months.

Groundwater levels were measured weekly in eighteen $7.5 \mathrm{~m}$ deep boreholes for 2 years. Hydraulic conductivities of the soil layers below the water table were estimated in these boreholes by measuring the rate of change in ground water depth after removing water with a bailer. Moisture contents at different soil suctions ( $\mathrm{pF}$ curves) were determined for the various soil horizons to derive soil moisture available for plants. To test the hypothesis that forest trees extract water directly from the groundwater even at a depth of several meters, some boreholes were monitored every 2 hours for 24 hours to detect diurnal variations in groundwater depths.

The storage coefficient for soil water is defined as the ratio of change in groundwater amount and change in groundwater table depth and corresponds more or less to the air filled pore volume of the soil at field capacity. The coefficient was calculated from the fall in groundwater level as a result of discharge, by analysing several periods with known groundwater level changes and discharges.

\section{Computer simulation}

To improve insight in the hydrology of the forest ecosystem and to estimate hydrological parameters that could not be measured, the relevant hydrological processes were simulated using a computer model. The model, adapted from the WOFOST model (van Keulen \& Wolf, 1986), simulates water use and growth of the forest, and soil moisture contents and groundwater depths.

The hydraulic characteristics of the area (high infiltration rate, insignificant overland flow, mainly groundwater discharge) made it possible to approximate the water movements with a one-dimensional model in which the 24-hour discharge is dependent on the groundwater level of the previous day.

Transpiration of the vegetation and evaporation of interception water had to be 
calculated. Class A pan evaporation values were transformed into potential evapotranspiration values $\left(E T_{0}\right)$ according to Penman. The relationship between Class A pan evaporation and $E T_{0}$ was calculated using data of a neighbouring meteo station. Maximum transpiration, i.e. transpiration at optimum water supply, of the forest $\left(T_{0}\right)$ was assumed to be related to $E T_{0}$ via de crop factor $\left(T_{0} / E T_{0}\right)$. Transpiration was reduced in the model at high soil moisture suctions.

Interception loss was defined as the difference in water use between a wet and a dry canopy under otherwise equal conditions. Transpiration was thus supposed to be independent of interception. Although these definitions of interception and transpiration are not according to convention, their operational use shows more clearly the influence of interception on water use.

Total water use of the forest over a period of several years can be calculated directly from the difference between rainfali and discharge in a confined catchment. Over shorter time periods, differences in soil water storage must be taken into account. The distribution of total water use during the study period, including wet and dry seasons, over daily totals was calculated with the simulation model.

The discharge equation in the original model which describes a steady state situation, was replaced by an equation describing transient (non-steady) flow that gave better agreement between measured and calculated discharges.

Measured data of rainfall, pan evaporation, available soil moisture and the storage coefficient were introduced into the model as forcing variables. For rooting depth, interception and crop factor various experimental values were used. Groundwater depth, soil moisture content, discharge, transpiration, and water storage were then determined by iterative simulation. Validation criteria for the model were discharge and groundwater levels (comparing measured and calculated values) and total amounts of water in the system at 'comparable moments' during the years, which should remain at the same level.

\section{Results}

Measured average annual rainfall and discharge were 2143 and $514 \mathrm{~mm}$, respectively. The length of the dry season (a period with less than $100 \mathrm{~mm}$ rain per month) varied between 2 and 5 months per year. The length of the period very little or no discharge varied between 0 and 8 months per year.

The 'best' simulation results of the water balance were obtained by a combination of an effective rooting depth of $450 \mathrm{~cm}$, a crop factor $\left(T_{0} / E T_{0}\right)$ of 0.87 and a maximum interception loss per rain day of $1.1 \mathrm{~mm} \mathrm{~d}^{-1}$.

Application of these system variables resulted in calculated daily discharges and groundwater levels that agreed well with measured values. In periods without water stress, transpiration rates varied from $5.7 \mathrm{~mm} \mathrm{~d}^{-1}$ in very sunny periods, to less than $2.8 \mathrm{~mm} \mathrm{~d}^{-1}$ in very overcast periods. Transpiration reduction due to water shortage occurred only at the end of very dry seasons and not every year. Interception losses (up to $1.1 \mathrm{~mm} \mathrm{~d}^{-1}$ ) were higher in the rainy seasons, but considerable losses also occurred in the dry seasons.

Total water use, defined as the sum of interception and transpiration $(I+T)$, was 
about equal to $E T_{0}$. For the whole study period $(I+T) / E T_{0}$ was 0.95 , but under wet conditions this ratio slightly exceeded 1 . In weeks with severe water stress it was reduced to a minimum of about 0.5 .

In the dry season, the contribution of the groundwater to water use by the vegetation appeared to be important, not only in the swampy valley bottoms with shallow groundwater, but also on plateaus and upper slopes where groundwater depth was more than $5 \mathrm{~m}$. This was concluded from diurnal variations in creek discharges and in groundwater levels in deep borings, and also from root observations and water balance simulations.

Computer simulation showed that interception losses led to increased water use in rainy seasons, but that in dry seasons total water use was still higher than in the wet season. The additional water use caused by interception was estimated to be 230 $\mathrm{mm} \mathrm{year}^{-1}$ at a total water use of $1640 \mathrm{~mm} \mathrm{year}^{-1}$.

\section{Conclusions}

Trees in the natural forest root very deep and extract water from the groundwater table, even when it occurs at depths below $5 \mathrm{~m}$. The high water use of the natural forest during the dry season, as observed in this study, is probably an important mechanism for conserving nutrients. Because soil moisture is replenished first, leaching is delayed in the beginning of the wet season. This is a crucial period as then many nutrients are mobilized as a result of fast decomposition of litter, collected during the preceding dry season.

\section{References}

Boxman, O., N. R. de Graaf, J. Hendrison, W. B. J. Jonkers, R. L. H. Poels, P. Schmidt \& R. Tjon Lim Sang, 1985. Towards sustained timber production from tropical rain forests in Suriname. Netherlands Journal of Agricultural Science 33: 125-132.

Graaf, N. R. de, 1986. A silvicultural system for natural regeneration of tropical rain forest in Suriname (Ecology and management of tropical rain forest in Suriname 1). Agricultural University, Wageningen, $269 \mathrm{pp}$.

Keulen, H. van \& J. Wolf (Eds), 1986. Modelling of agricultural production: weather, soils and crops (Simulation Monographs). Pudoc, Wageningen, 525 pp.

This synopsis is based on part of a doctoral thesis entitled 'Soils, water and nutrients in a forest ecosystem in Suriname' by R. L. H. Poels, Wageningen, Agricultural University, Wageningen, 1987, XII + 253 pp., 38 tables, 52 figs., 8 apps., 103 refs., in English, Dutch summary. Also published in the series 'Ecology and management of tropical rain forest in Suriname', Wageningen Agricultural University, Wageningen. Available as paper copy (order $R$ 098, $f 60$ including postage) at: $N A R D, c / o$ Pudoc, P.O. Box 4, 6700 AA Wageningen (telex 45015 bluwg $\mathrm{nl}$ ). 